Digital Press Social Sciences and Humanities

Gotong Royong in The Millennial Era

Nicholas Simarmata, Kwartarini Wahyu Yuniarti, Bagus Riyono and Bhina Patria

Proceeding of The 10th International Conference of Indigenous and Cultural Psychology 2019

Kwartarini Wahyu Yuniarti, Donald H. Saklofske, Rosnah Ismail, Saadi Lahlou (eds) 


\title{
Gotong Royong in The Millennial Era
}

\author{
Nicholas Simarmata ${ }^{1,}$, Kwartarini Wahyu Yuniarti², Bagus Riyono ${ }^{2}$, and Bhina Patria ${ }^{2}$ \\ 1 Psychology Study Program, Medical Faculty, Universities Udayana, Bali, Indonesia \\ 2 Psychology Faculty, Universitas Gadjah Mada, Yogyakarta, Indonesia \\ *e-mail: nicholas@unud.ac.id
}

\begin{abstract}
Gotong Royong is identified as old-fashioned, only thought to be practiced in villages and traditional activities, due to the tendency for Millennials to participate in modern activities that tends to make them anti-social. However, when KOMPAS put out polling with the question, "Is there still Gotong Royong in this millennial era," as much as $63.5 \%$ of the respondents said that there are Gotong Royong activities in their neighborhood. Additionally, as many as $53.2 \%$ of respondents felt satisfied with the government's attempt to institutionalize the cultural value in several sectors. Also, more than $70 \%$ of the respondents stated that the spirit of Gotong Royong is still embedded in society. This fact implies that the spirit of Gotong Royong is still actively practiced by Indonesians living in both rural and urban areas. Gotong Royong could transcend in any future era because it is a value deeply embedded in the Indonesian people.
\end{abstract}

\section{Keywords}

gotong royong, millennial era, national identity

\section{Introduction}

Gotong Royong is originally a Javanese term (Pranowo, 2010), but it has officially been added as an Indonesian word that means bringing, carrying, or lifting heavy things together with somebody else. In Indonesia, people would readily and voluntarily aid their neighbors in preparing for any event to lessen their neighbors' workload. As a result, the preparations for the celebration can be done at a faster pace without any real difficulty. Neighbors also feel that they have used their collective work as a form of social solidarity in a positive way.

Gotong Royong is the collective behavior that has contributed to Indonesia's popularity of having a friendly and welcoming attitude toward others. Indonesians have practiced Gotong Royong since ancient times that some regarded it as an old-fashioned or an out-of-date behavior (Agustian, 2016; Anggorowati \& Sarmini, 2015; Asnudin, 2010; Bintari \& Darmawan, 2016; Bintarto, 1980; Effendi, 2013; Hardiman, 1980; Harmoni, 2015; Latif, 2017; Muryanti, 2014; Mustaqim, 2013; Pasya, 1987; Pranadji, 2009; Purna \& Wahyuningsih, 1996; Putnam, 1993; Rizqi, 2017; Sadilah, Mudjijono, \& Budi, 2015; Salsabila, 2017; Sarwono, 2017; Sudarmadji \& Darmanto, 2014; Sugiyanto \& Khamadi, 2011; Suprihatin, 2014; Surbakti, 2009; Suwondo, 1982, 1983a, 1983b; Swasono, 2017; Takwin, 2015; Thomas, Selvadurai, Er, Lyndon, \& Moorthy, 2011;Yunus, 2013). However, due to globalization and the development of media technology, which gave birth to the generation of Millennials, some Indonesians feel that the spirit of Gotong Royong is gradually vanishing from the Indonesian character (Pranowo, 2010). There have been comments that Gotong Royong is an illogical behavior because it is no longer appropriate to do due to the different demands of modern life (Sugiyanto \& Khamadi, 2011). This kind of thinking becomes interesting to follow-up through library research of what became the original concept of Gotong Royong. Wasn't Gotong Royong the basis for Indonesia's ideology, Pancasila? Why then, would some people become afraid that it is no longer valid for Indonesians to do? Some scholars have debated over removing this national identity (Effendi, 2013; Hardiman, 1980). However, questions have appeared of whether removing it to ensure Indonesia is within the circle of countries that support the needs of the millennial era would be deemed correct. Can Gotong Royong still be used in the sectors of Technology, Education, Economics, Humanity, Arts, and Economy of this millennial era? This article attempts to answer these questions by revisiting the conceptual idea of Gotong Royong, how it has developed, and how it may be affected by the Millennial generation. 


\section{Literature Review}

\subsection{Millennial Generation}

The millennial generation refers to people born between 1981-2000 (Ali \& Purwandi, 2017). This generation was born into an era of gadgets and the internet, providing unlimited access to local and international information. The previous generation before them is limited by national borders, making it harder for them to achieve a global-level interaction. Meanwhile, Millenials are only one click away from having and promoting something they need from a far-away place. As such, the importance of socializing with others to obtain information is not so much a priority for millennials as it was for older generations.

The frequent use of the internet and gadgets causes the Millennial generation to be known as the google generation, net generation, and echo boomers (Ali \& Purwandi, 2017). Using their smartphones, they rely on various social media (i.e., Facebook, Instagram, Twitter) to be well-informed and communicate with other gadget enthusiasts. Google and Youtube often became some of the primary ways to learn something new. Interestingly, his daily activity gave them the claim as innovators of the century.

The Millennials are known to be characterized by 3Cs, i.e., they have ways to be continually "connected, creative, and confident" with themselves. First, they are always connected to the internet. Second, they are creative with their often out-of-the-box ideas. Third, they are confident with what they have and feel they do not need to obtain any help or advice from their parents and neighbors (Ali \& Purwandi, 2017). It is this last point that the older generation regards the Millennial generation to be anti-social and become a factor for not seeing the importance of continuing the Gotong Royong attitude.

\subsection{Indonesia's Concept of Gotong Royong}

Gotong Royong as a concept has been defined and practiced in many ways. One of the definitions of Gotong Royong, as exclaimed above is as an attitude. Other scholars see Gotong Royong as a behavior, a form of collective activity, a form of explicating good relations with others, a show of embracing diversity, and the importance of mutual teamwork. Below are the details for each of the concepts.

\subsubsection{Gotong Royong as An Attitude.}

It is a positive attitude and energy for the unity (Ariyantoni, 2014; Hudalah, Zulfahmi, \& Firman, 2013; Kamsori, Santosa, \& Moe'is, 2007; Nelson, 2008; Pranadji, 2009; Rochmadi, 2012; Wachtendorf, Brown, \& Nickle, 2008; Yuniarti, 2009) to achieve a determined result (Djamari, 2016). The attitude is usually carried out spontaneously without any intention of receiving any kind of profit (Gunardo, 2013) to help others who are weak to ensure that a collective prosperity is met (Sutrisno, 2017).

\subsubsection{Gotong Royong as A Social Behavior.}

It is an actual social behavior (Bintarto, 1980; Pranadji, 2009; Simarmata et al., 2017) that creates a social structure (Bintarto, 1980). Within the social structure, people who perform Gotong Royong have the opportunity to implement harmonious and circumstances for solid social connections (Bowen, 1986; Guinness, 1986, 1994; Kusumasari \& Alam, 2012; Rigg, Allott, Harrison, \& Kratz, 1999; Sugiyanto \& Khamadi, 2011; Zakaria, 2017).

\subsubsection{Gotong Royong as A Collective and Communal Action.}

This implies that Gotong Royong is only possible when an individual is working together with another individual or community (Duwata, 2013). It is an action that springs from a communal consensus. As a social interaction that relies on collective behavior (Bowen, 1986; Ghazali, 2013; Macrae, 2008; Pattiradjawane \& Soebagjo, 2015; Pranadji, 2009; Rigg et al., 1999). Gotong Royong implies a collective social routine (Mohamad, Idris, \& Mamat, 2012) that values the sharing of a working load (Ghazali, 2013; Hudalah et al., 2013). Gotong Royong is applied by Indonesian people to represent the local ethics or collective behavior that is organized in a society or the environment around it (Pierewan \& Sujarwoto, 2010).

Gotong Royong occurs as a tradition of communal or collective working strategy (Braithwaite, 2014) because the people in South-East Asia (like Indonesia) has produced indigenous forms of communalism and collectivism which place the importance of coming together as a group (Bourchier, 1998; Hofstede, 1994; Jetschke \& Rüland, 2009; Kawagoe, Ohkama, \& Bagyo, 1992; Rother, 2007; Saliyo, 2012; Sihombing 
\& Pongtuluran, 2011) to solve problems together (Tjahjandari, Setyani, Pembayun, \& Kurnia, 2017). This communal characteristic contributes to a strong social relationship (Rahmi, Wibisono, \& Setiawan, 2001; Yatmo, Atmodiwirjo, \& Paramita, 2013) between others to do collective activities in people's daily lives (Sagala, Okada, \& Paton, 2009). Gotong Royong is, therefore, a practice that shows the importance of maintaining a good relationship to achieve social solidarity (Darmaatmadja, 2017; Sumarijanto, 2013).

\subsubsection{Gotong Royong as A Relational Activity.}

Human is a creature who needs interaction with others and their surroundings, in order to grow and develop well. Through interaction with others, human beings living in a social group feel the benefits of having a close relationship and teamwork from and with others. These circumstances, practices, communication, and inter-relational activities have become the characteristics of Gotong Royong (Abdillah, 2011; Simarmata et al., 2017). Gotong Royong, thus, has a basic perspective that everyone cannot live without others (Bintari \& Darmawan, 2016; Bintarto, 1980; Simarmata et al., 2017) but they need other people in many ways, such as for interaction, working together, helping each other, and doing community service to feeling a secured life in their social surrounding (Kayam, 1987).

\subsubsection{Gotong Royong Embraces Diversity.}

Indonesia has a population of 258,705,000 people (Asean Economic Integration Brief, 2017), formed by diverse race and ethnic groups (Yuniarti, 2015). Thus, Indonesia is one of the most ethnically diverse nations (Aristiarini, 2017). There are in fact 1,340 ethnics in Indonesia (Badan Pusat Statistik, 2010). This means that there are various ethnic traditions, wisdom, and cultures that set Indonesia apart from many other countries (Ariyantoni, 2014; Prawitasari-hadiyono et al., 2009). There are also around 1,158 traditional languages in Indonesia (Badan Pusat Statistik, 2010), allowing diverse local cultures to appear in Indonesia (Darwin, 2009). These local cultures can be viewed in many ways, such as through their dialects and accents (Tsamenyi, Noormansyah, \& Uddin, 2008).

The word bineka in Indonesia's motto, first appeared during the Majapahit Empire in 1293 when Mpu Tantular wrote the Sutasoma book containing the sentence "Shiwa-Budhha Bhinneka Tunggal Ika, Tan Hana Dharna Mangrwa". This sentence means that the Hindu and Buddha religions are different, but they are united since they both agree that truth is never ambiguous (Pattisina \& Anggoro, 2018). The Indonesian motto, Bhinneka Tunggal Ika, thus, contains the lesson that Indonesians should give high respect to the concept of Gotong Royong (Lembaga Ketahanan Nasional Republik Indonesia, 2015). Diversity as one of the characteristics of the many islands and cultures of Indonesia has become the strength of Gotong Royong itself (Susanto, 2016). This is because Gotong Royong is identical to the diversity of the Indonesian people (Bowie, 1955; Syamsuddin, 2016).

Gotong Royong gives opportunities for the Indonesian people to interact with Indonesia's diversity in religion, ethnic, educational, and social backgrounds. This means that Indonesia cannot avoid itself from diversity, because if there is no diversity, then there will be no Indonesia (Prasetyo, 2009). Thus, as mentioned before, diversity becomes a strength that supports and completes one to another (Alfian, 2018).

Diversity in Indonesian society is an amazing capital and potential for collective development if it is processed with the spirit of Gotong Royong. It is the spirit of Gotong Royong that enables the existence of all elements in Indonesia to become admitted. It is also the concept of Gotong Royong that makes pluralism develop well.

Deepening the value of Gotong Royong is highly needed in developing nationalism in the diverse Indonesian islands (Dewantara, 2017a, 2017b, 2017c). Gotong Royong is the element that produces unity in Indonesian people's diverse life (Anggorowati \& Sarmini, 2015; Bintarto, 1980). It is also Gotong Royong that creates dialogue, so that there is a consensus from many kinds of social level, in order to strengthen the unity of this nation (Bintarto, 1980).

\subsubsection{Gotong Royong is A Mutual Form of Activity.}

Gotong Royong means helping each other (Agustian, 2016; Bowen, 1986; John Braithwaite, 2011a, 2011b; Carnegie, 2010; Fearnley-Sander, 2000; Geertz, 1983a, 1983b; Hasan \& Onyx, 2008; Hudalah et al., 2013; Jamal \& Pomp, 1993; Magnis-Suseno, 1997; Marcillia \& Ohno, 2012; Rafik-Galea, Mello, \& Dass, 2013; Rajiani \& Jumbri, 2011; Reimer, 1995; Salehudin, Prasad, \& Osmond, 2013; Takwin, 2015) , lightening each other's work loads (Pasya, 1987), developing each other, making each other great (Guinness, 1994; Gunardo, 2013; Zakaria, 2017), respecting each other and honoring each other (Bintari \& Darmawan, 2016; Fathurokhman, 2013; Ghazali, 2013; Guinness, 1986; Hasan \& Onyx, 2008; Purna \& 
Wahyuningsih, 1996; Sugiyanto \& Khamadi, 2011; Takwin, 2015), making each other prosperous (Blackburn, 2004; Panglaykim, 1965; Rahmi et al., 2001; Zanegoebel, 2010) requiring each other (Khasanah, 2013), inspiring each other (Braithwaite, 2011, 2011b; Salehudin et al., 2013), supporting each other (Baswedan, 2015; Swasono, 2017), and completing others' weaknesses to achieve collective prosperity (Sutrisno, 2017).

In the spirit for a mutual consensus, Gotong Royong motivates people to help each other sincerely (Baswedan, 2015; Bowie, 1955; Brahmana, Rochayanti, \& Susilo, 2009; Geertz, 1983a, 1983b; Kamsori, Santosa, \& Moe'is, 2007; Kemendikbud, 2014, 2014; Newberry, 2007; Sadjad, 2013), in people's social lives to finish any activities (Saraswati, 2011), work, or problems (Kamsori, Santosa, \& Moe'is, 2007) easily. Besides, living together by helping each other through Gotong Royong without looking at anyone's religious background is one way to build up brotherhood in Indonesian society (Darmaatmadja, 2017; Harjosusanto, 2017).

\subsubsection{Gotong Royong is Teamwork.}

In doing something mutually together, Gotong Royong needs Indonesian people to do teamwork (Djamari, 2016; Soedirham, 2012; Tjahjandari, Setyani, Pembayun, \& Kurnia, 2017). In fact, Gotong Royong is an indigenous form of dynamic teamwork (Adamson, 2007; Agustian, 2016; Azman, Halim, Liu, Saidin, \& Komoo, 2010; Baker, 2006; Bintari \& Darmawan, 2016; Blackburn, 2004; Bowen, 1986; Djamari, 2016; Duwata, 2013; Farisi, 2014; Fathurokhman, 2013; Geertz, 1983a, 1983b; Goodfellow, 1997; Goodwin \& Giles, 2003; Harnoko \& Salamun, 2016; Hisyam, 2003; Irawanto, 2015; Kamsori et al., 2007; Kayam, 1987; Khasanah, 2013; Koentjaraningrat, 1961, 1967, 1988; Kusumasari \& Alam, 2012; Lim, Chan, Alsagoff, \& Ha, 2014; Manurung, Sumarto, Komariya, \& McIntyre-Mills, 2009; McCarthy, 2014; Mustaqim, 2013; Nasution, 2010; Newberry, 2007; Pasya, 1987; Rahmi et al., 2001; Rochmadi, 2012; Sadjad, 2013; Sillifant, 1994; Soekamto, 1986; Suwondo, 1982a; Swasono, 2017; Taylor \& Aragon, 1991; Zanegoebel, 2010). It is not a conspiracy (Swasono, 2017) to achieve a positive outcome from a defined goal, i.e. through consensus and discussion (Effendi, 2013; Rochmadi, 2012) that is oriented in the benefits of being united in citizenship (Satrijono, 2012), it is a strategy of fulfilling the necessities and the facing of problems collectively to achieve a defined goal (Djamari, 2016; Soedirham, 2012).

Teamwork starts from a willingness to do Gotong Royong in order to achieve a collective business as well as possible. Teamwork is a collective strategy to support and give benefits to each other. Gotong Royong is not a way to point out the weaknesses and peep others' idleness, nor is it to humiliate and steal other people's insights because they are careless in showing it to others. Gotong Royong values people to work together and in completing the work, the result is shared and enjoyed by everyone involved, fairly (Sutrisno, 2017). To continually make Gotong Royong a form of agreed social teamwork (Swasono, 2017) that gives out benefits, the Indonesian people are taught to be ready with exchanging good favors with one another (DeMeulenaere, 2002).

\section{Method}

This article reports on the Indonesian cultural value of Gotong Royong by use of library research in its method. With library research, data about the meaning, and application of Gotong Royong in the Millennial era is obtained by tracking articles, books, or journals either in printed form or from the online resources made available by going through the Google facility and several Journal Websites subscribed by Universitas Gadjah Mada.

\section{Discussion}

\subsection{Millennial Generation's Opinion About Gotong Royong}

With all of the good points informed through the literature study of Gotong Royong's concepts, is it really true that the Millennial generation prefers for this national identity to be discontinued? In the interest of finding out whether or not Gotong Royong is still an important value for the Millennial generation, KOMPAS (2015) made polling about it. The first opinion polling was given through a question, "In the past 
month, is there an activity that shows the application of Gotong Royong in your place?" The responses varied: 63,5\% answered "There is Gotong Royong activity", 36,3\% answered "There is no Gotong Royong activity.", and 0,2\% answered, "I do not know/I do not answer." With 63,5\% answering "Yes", it shows that Gotong Royong activities are still important to exercise in Indonesia.

The second opinion polling was given through the question, "Are you satisfied with the performance of the government in developing a culture of Gotong Royong?" In response to this question, there were $53,2 \%$ answered "Satisfied", 42,8\% answered "Unsatisfied", and 4\% answered, "I do not know/I do not answer." The response of more people saying satisfied rather than unsatisfied also means that Gotong Royong activities are still important to do in Indonesia.

The above polling was done by phone, by the Research and Development Department of KOMPAS on December 2-4, 2015. There were 587 respondents with the minimum age of 17 years-old who were randomly chosen from the newest phone book. The respondents live in 12 big cities in Indonesia. In the trust level of $95 \%$, the sampling mistake of this research is $\pm 4 \%$ (Saputra, 2015). The positive answers about the continued importance of Gotong Royong activities are proof that people's assumption of the value vanishing from the culture in the Millennial era in Indonesia is found wrong.

Additionally, another survey from KOMPAS about social adhesiveness that was held in July-August 2016 showed that the social capital in society is still strong. There were more than $70 \%$ of respondents who said that the spirit of Gotong Royong is still with the people around them (Sultani, 2016). This showed that the spirit and culture of Gotong Royong among people is still quite high (C. K. Putra \& Pratiwi, 2013; Salamun, Sumintarsih, \& Wuryansari, 2015).

\subsection{Gotong Royong in The Government Sector of The Millennial Era}

Gotong Royong appears in many aspects of people's lives in Indonesia. In the government sector, Megawati Soekarnoputri (the fifth President of Indonesia in 2001-2004) applied Gotong Royong as the name of her cabinet, (Pranowo, 2010), to give an orientation that the administration would be done collectively from any sources to gain teamwork (Khasanah, 2013).

Susilo Bambang Yudhoyono (the sixth President of Indonesia in 2004-2014) also used Gotong Royong as the name of his cabinet, which was First (I) Gotong Royong Cabinet and Second (II) Gotong Royong Cabinet (Pranadji, 2009; Rochmadi, 2012).

Joko Widodo (the seventh and eighth President of the Republic of Indonesia in 2014-2024) emphasized the importance of Gotong Royong (Sambhi, 2015) as the base of collaboration and synergy between individuals (Agustian, 2016) that includes the value of teamwork, high solidarity, and communalism (Sarwono, 2017). Joko Widodo, or popularly known as Jokowi, envisions the continued success of the independence of Indonesia through characters based on Gotong Royong. In other words, Gotong Royong becomes an important point for the Indonesian people to have as an ideal principle (Kurniawan, 2015). He also proposed the national movement of the Mental Revolution, which leads to the independence of Indonesia to keep sovereignty through characters based on Gotong Royong (Pattiradjawane \& Soebagjo, 2015; Zakaria, 2017).

Gotong Royong becomes one of the focused aspects in Peta Jalan Gerakan Nasional Revolusi Mental (2015-2020) that is composed as a guide to making sovereignty, independence, and character of the nation for the Indonesian government and society to have integrity and ethics (Satrijono, 2012). Gotong Royong also becomes one of the strategic values to be developed by the principle of the Mental Revolution (Wirutomo, 2015a, 2015b), because it is the core value of the Mental Revolution that based itself on the ideal culture value of Gotong Royong. Through Gotong Royong, the purpose of the Mental Revolution, which wants to create Indonesian people who have integrity, the willingness to work hard, and do Gotong Royong (Mahkamah Konstitusi Republik Indonesia, 2017) can be achieved.

Gotong Royong, which can only be fulfilled through teamwork of helping each other in kindness and development (Latif, 2015) is an essential value that has to be internalized either among individuals or in the national scope. Gotong Royong, therefore, becomes the base of the principle in Kabinet Kerja 20152019, which creates Indonesia to have sovereignty, confidence in protecting regional sovereignty, economic independence by protecting maritime resources, and in reflecting the personality of Indonesia as an archipelago state (Kementerian Perencanaan Pembangunan Nasional/ Badan Perencanaan Pembangunan Nasional, 2014a, 2014b).

Gotong Royong is thus, one of the agendas of the National Long-Term Development Plan (Kementerian Perencanaan Pembangunan Nasional/ Badan Perencanaan Pembangunan Nasional, 2014a, 2014b; Sekretariat Negara Republik Indonesia, 2007), which wants Indonesia to be strong, competitive, noble, and have morality based on Pancasila (Kemko Kesejahteraan Rakyat, 2010). 
Sman Abnur (the sixteenth Minister of Administrative Reform and Bureaucratic Reform of the Republic of Indonesia in 2016-2018) says that Gotong Royong is supported by Mental Revolution so that the integrity of development in the level of the ministry/institution/local government becomes strengthened (Zakaria, 2017). Meanwhile, Tjahjo Kumolo (the 28th Minister of Home Affairs of the Republic of Indonesia in 2014-now) also says that Gotong Royong has become the principle of Mental Revolution, thus it must be implemented concretely and developed in many dimensions so that it covers all aspects of Indonesian national life (Zakaria, 2017) .

Khofifah Indar Parawansa (the 27th Social Minister of the Republic of Indonesia in 2014-2018) says that Gotong Royong is a result of the improvement of people's life quality, where the Indonesian people is understood as resources who are productive and competitive (Zakaria, 2017). Anies Rasyid Baswedan (the 27th Minister of Education and Culture of the Republic of Indonesia in 2014-2016) has a dream aiming to create talented people and education and culture, with an ecosystem that has good characters based on Gotong Royong (Baswedan, 2015).

Puan Maharani (the 16th Coordinating Minister for Human Development and Culture of the Republic of Indonesia in 2014-now) says that Gotong Royong becomes one of the visions in the national development of the National Medium Term Development Plan (RPJMN) in 2015-2019. It also becomes the prerequisite of the National Movement of the Mental Revolution that is determined by the Coordinating Ministry for Human Resources Development (Kemenko PMK) (Maharani, 2015; Prabowo, 2015; Solihin, 2015).

Soedijarto as the speaker of F-UG (Fraction of Group Delegate) says that the spirit of Gotong Royong is needed in holding a state (Mahkamah Konstitusi Republik Indonesia, 2010). Tri Risma Harini (the 23rd Mayor of Surabaya in 2010-now) also participates by doing Gotong Royong as a service and assistance for her people. Through the principle of Gotong Royong, she changed the city park to become cleaner, more orderly, and beautiful (Zakaria, 2017). Sri Sultan Hamengkubawana X (the Third Governor of Daerah Istimewa Yogyakarta in 1998-now) also launched an independence movement for the people of Yogyakarta through a motto of Segoro Amarto (Semangat Gotong Royong Agawe Majune Ngayogyokarto) which means the spirit of Gotong Royong for the development of Yogyakarta.

As learned from the above governmental leaders, Gotong Royong activity is still important to do in the Millennial era. It is a part of the goals of village development as determined by the Constitution No. 6/2014 about how a village must improve people's prosperity and human's life quality and poverty prevention through the fulfillment of basic necessities, village facilities and infrastructure, development of local economy, and the utilization of natural resources and the environment by continually prioritizing on togetherness to create peace and social justice (Kementerian Perencanaan Pembangunan Nasional/ Badan Perencanaan Pembangunan Nasional, 2014a, 2014b).

Gotong Royong has become an elaboration of TRISAKTI, which consists of (1) People's sovereignty of character, value, and spirit that need to be built through national unity, and (2) People's personality in a culture that is realized through character reinforcement based on the reality of diversity, and (3) the nation's maritime, which is the strength of the national potential in creating an implementation of political and economic democracy of Indonesia in the future (Kementerian Perencanaan Pembangunan Nasional/ Badan Perencanaan Pembangunan Nasional, 2014a, 2014b; Setiawan, 2013).

In the Indonesian government, Gotong Royong is a strategy in the financial resource of the organization of the Family Welfare Development (Pembinaan Kesejahteraan Keluarga-PKK), too. It is in one of its ten programs that reflects the basic necessities of Indonesian people based on the Decree of the Minister of Home Affairs and Regional Autonomy No. 53 in 2000 about the Family Welfare and Empowerment Movement (Aslichati, 2011).

Additionally, the Indonesian Military participates also in Gotong Royong in rebuilding people's houses in Poso, Sulawesi in which the people became the victims of the previous Poso turbulence. Gotong Royong has changed the heart and mind, to recover relationships, by forgiving, apologizing, and helping each other. The post-conflict reconciliation in Indonesia is only possible by Gotong Royong (Braithwaite, 2014).

Meanwhile, the Directorate General of Taxation (Direktorat Jenderal Pajak-DJP) has also implemented the principle of self-assessment by using Gotong Royong, which created DJP employees into one soul to emphasize on extensification dialogue for better taxpayers (Saputra, 2015). Gotong Royong is, thus, still an important cohesive for all government matters. How is it in other sectors?

\subsection{Gotong Royong in The Technology Sector}

In the technology sector, Gotong Royong exceeds the social, religion, and ethnic background (Dewi, 2007). The supreme value of Gotong Royong is still done in parallel with people's tendency in using digital 
devices. The purpose of https://kitabisa.com/ is to raise the spirit of Gotong Royong through digital media (Timur, 2016). Pulse Lab Jakarta creates a word list of disasters by involving as many people as possible to give contribution through Gotong Royong in a form of game entitled Translator Gator so that it can be used by organizations who want to monitor the social media to receive an early warning or information related to a specific disaster (Riyadi, 2017).

The government of Banyuwangi Regency (https://smartkampung.id/) also gives out easy access for people who want to point out available projects. The movement of Indonesia $\mathrm{X}$ through (https://www.indo nesiax.co.id/) has also given service to fulfill learners' needs by giving free daring courses every day. It is learned from the Information and Communication Technology (TIK) that the internet as its prime facility is basically a form of electronic Gotong Royong (Sudarto, 2006). In other words, Gotong Royong still exists in Indonesia as it is the power for the digital technology era, it (Rahayu, Ludigdo, Irianto, \& Nurkholis, 2015).

\subsection{Gotong Royong in The Economy Sector}

In the economic sector, the strength of Gotong Royong comes from the wide and prosperous participation, known as the sharing economy. The sharing economy is an innovation in both products and business models. Some examples are the previously discussed Kitabisa (https://kitabisa.com/). It is a social platform to dispense kindness in the form of crowdfunding.

Akseleran (https://www.akseleran.com/) is a peer-to-peer lending platform in which everybody can give an easy, safe, and profitable business loan to small and medium enterprises (UKM) and for those categorized as initial businesses. Gotong Royong Fund in (http://www.gotong royong.fund/) is a fundraising platform in Indonesia that works on communities of fundraising either by individuals or organizations, in the sector of social, education, health, creative idea, and many others to achieve the same goal.

Gandeng Tangan (https://gandengtangan.org/) is a collaboration platform that uses the spirit of Gotong Royong. It is for business owners who need funding with investors who want to give social impact safely and transparently. Lastly, Kolase (https://www.kolase.com/) is a crowdfunding site that becomes the first online joint venture of music in Indonesia (Kasali, 2017) that carries with it the spirit of Gotong Royong, too.

\subsection{Gotong Royong in The Education Sector}

In the education sector, a learning method of Gotong Royong (Cooperative Learning) has been developed. The learning activity which gives chances to the learners to cooperate with their peers (Satrijono, 2012). The strategy to improve students' participation in learning is done by making innovation in the learning process, and one of those ways is by Gotong Royong or group learning (Musthofa, 2013). Students work with their peers in Gotong Royong circumstances, so that they all have many chances to process information and improve their communication skills (Lie, 2002; Musthofa, 2013). The learning method of Gotong Royong (Cooperative Learning) can be defined as a working system for a structured group learning that can improve students' learning outcomes (Garfield, 1993; Indiyani \& Listiara, 2006; Lie, 2002). The learning method of Gotong Royong (Cooperative Learning) is suitable to be implemented in the Indonesian education system since this learning method applies the principle of Indonesia's spirit of Gotong Royong (Indiyani \& Listiara, 2006). This means Gotong Royong can be used as the main value in the concept of Character Education Reinforcement brought by the Ministry of Education and Culture (Abduhzen, 2016) because it is a value that is taught in schools to support students as intellectual candidates (Joesoef, 2017).

Games that emphasize the value of Gotong Royong has been found in traditional games that are played in groups. The value of Gotong Royong contained in traditional games teaches children to help one another to achieve victory (Departemen Pendidikan dan Kebudayaan, 1997; Susanti, Siswati, \& Widodo, 2010). That value of Gotong Royong sharpens children's emotional skills because, in Gotong Royong, they must have empathy and give some effort to help their friends who face difficulties (Susanti, Siswati, \& Widodo, 2010). 


\subsection{Gotong Royong in The Humanity Sector}

In the humanitarian sector, when there was a tsunami in Aceh in 2004, all Indonesian people, starting from children until adults, spared some of their wealth for people in Aceh. The same way also happened when there was a disaster in Yogyakarta, West Java, and many others. Sparing some of the people's wealth is exercising the spirit of Gotong Royong. With some children found sick but could not afford to see doctors due to the expensive cost, it has influenced television and newspaper reporters to help raise people's willingness to help the victims of the tsunami effect. One of the realizations was seen in the gathering of funds for Bilqis Anindya Passa who needed around one billion rupiahs for her heart anomaly disease (Pranowo, 2010).

On May 26 $6^{\text {th }}, 2006$, many people's houses were damaged due to the earthquake experienced by the Bantul Regency, of Daerah Istimewa Yogyakarta. Through the spirit of Gotong Royong, television and newspaper reporters were able to attract foreign news reporters to also make a special review about the event. As a result, foreign agencies and Non-Government Organizations (NGOs) came along with local NGOs to help rebuild the people's houses and buildings. This collective participation in rebuilding cannot be done if the people have no awareness of Gotong Royong culture (Samawi, 2016). The culture of Gotong Royong remains strong in the neighborhood association (RT), citizen association (RW), hamlets, villages, village meetings, Village Consultative Institutions (Badan Permusyawaratan Desa-BPD) and other local institutions (Effendi, 2013).

\subsection{Gotong Royong in The Art, Sport and Health Sector}

In the art sector, Indonesia's platform of culture is developed based on the concept of Gotong Royong. One of the international cultural events that was held using Gotong Royong platform is the International Gamelan Festival in Solo in 2018. In the area of sport, the key success of the Asian Games in 2018 is also because of the spirit of Gotong Royong that makes a collaboration of communal work from the government, private offices, and the people around the area (Thohir, 2018).

In the area of health, the acceleration of social assurance membership for informal workers has involved the Social Security Administrator of Employment to prepare a mechanism to involve corporations to give funding through Companies' Social Responsibility (CSR) involvement. The CSR accommodates the donation companies agree to contribute to the better health of people who are informal workers. If it was not for the spirit of Gotong Royong, the CSR may not have the opportunity to help people who need to donate funding for their better health (Handoko, 2016).

\subsection{Gotong Royong in The Social Sector}

In the social sector, the program of Ayopeduli (http://ayopeduli.id/) is a collaborative platform of social actions to invite people to actively participate in helping social actions. Members of a Credit Union, like Keling Kumang, in Ansok Village, Sintang Regency, West Kalimantan do Gotong Royong in building eight micro hydropower plants (Pembangkit Listrik Tenaga Mikro Hidro-PLTMH) (Munaldus, 2015).

The spirit of Gotong Royong is also shown by the people who wanted to help Prita Mulyasari to fight against the International Omni Hospital, by collecting funds for Prita to pay for her prosecutors (Pranowo, 2010).

Through Komunitas Bogor Sahabats (Bobats) the action led by Gatut Susanta, Hazairin Sitepu, and Imam Soeseno, have realized Bogor with its Gerakan 5 juta lubang biopori (Kementerian Koordinator Bidang Pembangunan Manusia dan Kebudayaan, 2015).

Villagers in Malang Regency, East Java also promoted the national personality of Gotong Royong by doing voluntary fundraising to build facilities, which was a Posyandu hall as a place to hold many kinds of activities. The spirit of Gotong Royong is not rarely done by people (Harinto, 2018). The three houses of worship (Islam, Christian, Buddha) that are now in The Kelan Hamlet, Batur Village, Getasan Sub-District, Semarang Regency, Central Java Province, were built through the mutual collaboration based on the Gotong Royong (Irawan, 2018).

House renovation programs can also be funded through a Gotong Royong voluntary donation from companies, public figures, and civil servants (Pegawai Negeri Sipil-PNS) like experienced by the Kulon Progo Regency. In the regency, every month a Gotong Royong donation of two hundred and seventy million rupiahs is done by the civil servants of Kulon Progo. "It turns out that the Gotong Royong project is successful," said Hasto Wardoro (the regent of Kulon Progo, DIY Province) (Firdaus \& Riatmoko, 2015). 
In addition to the above example, the spirit of Gotong Royong was also done by the people of Yogyakarta during the preparation and implementation of the 261st birthday of Yogyakarta city. The event of "Dhahar Kembul Tumpengan Pancasila" attended by Sultan Hamengku Buwono X (Governor of DIY Province) and his wife, GKR Hemas, Paku Alam X (Vice Governor of DIY Province), Ganjar Pranowo (the General Chair of Kagama and Governor of Central Java), Mahfud MD (Member of Steering Board of the Pancasila Ideology Development Institution) in Malioboro, Yogyakarta came to implement the essential value of Gotong Royong, ie. the Pancasila. The event gathered volunteered around 30 community groups to freely provide tumpeng for people's meals (Putra, 2018). Gotong Royong is one of Indonesia's main strengths to stand strong and actively participate in the global area, as what was mentioned by Soekarno (the first President of the Republic of Indonesia), who is the founding father of Gotong Royong.

\subsection{Gotong Royong in The Organization Sector}

In the organization sector, Gotong Royong among divisions is a necessity (Zakaria, 2017). Loyalty and solidarity are strongly emphasized in work units since the principle of Gotong Royong influences people's daily lives (Gani, 2004; Irawanto, 2015). Gotong Royong is a working method that is mostly done in Indonesia and it can be explained descriptively as something that has to be done together, where people learn from each other in their activities.

In the principle of Gotong Royong, people would work both physically and spiritually with others to ensure respect for the group work agreed to be done together (Effendi, 2013). This reflects Gotong Royong's strong emphasis on social solidarity and in the co-dependent relationship among members of an organization (Tsamenyi et al., 2008). Through Gotong Royong, people are encouraged to be involved psychologically and emotionally to one another (Wihantoro, Lowe, Cooper, \& Manochin, 2015). The social solidarity characteristic of Gotong Royong becomes a positive attitude since it helped create a solid and effective team (Panggabean, Tjitra, \& Murniati, 2014) to contribute what each member can afford (Pranowo, 2010).

Gotong Royong also reflects the character of Indonesian employees (Kaming, Holt, Kometa, \& Olomolaiye, 1998) who because of Gotong Royong, the productivity of a company becomes high. This is based on a company's approach, which is orients in the social motivation and social awareness of others' well-being in a workplace (Rachman \& Savitri, 2011). With Gotong Royong, a company can create energetic human resources (Sumber Daya Manusia-SDM) and team harmonization in order to achieve a company's defined target (Zakaria, 2017).

Gotong Royong is one of the three Indonesian values that are compatible with the skills of people in the 2000s (Toisuta, 2017) or the Millennial era so that Indonesia can compete with other nations at the global level (Wahid, 2016). By fighting for the implementation of a modern Gotong Royong, the life of the Indonesian people can be stronger than before (Suryohadiprojo, 2016). This becomes the strong reason why Joko Widodo (the seventh President of the Republic of Indonesia) says that Gotong Royong is still needed among the government, the Indonesian people, and the private companies (Latif, 2014; Zakaria. 2017). In this way, effective participation exists from the social agents of the civil society, media community, and workers in the culture, education, and business sectors (Latif, 2015).

\section{Conclusion}

The spirit of Gotong Royong in the Indonesian people has been questioned in its popularity and effectiveness due to the Millennial Generation's characteristics of not wanting to socialize as much as their older generations. However, through polling done by KOMPAS and an analysis of how Gotong Royong is implemented in sectors of education, economy, health, art, technology, etc, this assumption is found to not be true. Gotong Royong in the Millennial era is still highly practiced by Indonesians. Although there are some changes in its formations, the meaning and application of Gotong Royong still exist and will not be extinct. The shift of cultural values in Gotong Royong cannot be considered as the extinction of the Indonesian cultural value of Gotong Royong. Some form of attitude in Gotong Royong may change slightly, due to having it more suitable with the available technology and scientific advancement in supporting the Indonesian people. The cultural value of Gotong Royong is highly honored in every moment by those living in either rural or urban areas because it is a value that is embedded deeply in the Indonesian people. 


\section{Reference}

Abdillah, B. (2011). Gotong Royong Cermin Budaya Bangsa Dalam Arus Globalisasi. Yogyakarta: AMIKOM.

Abduhzen, M. (2016, October 27). Pendidikan Karakter Bangsa. KOMPAS.

Adamson, C. (2007). Gendered Anxieties: Islam, Women's Rights, and Moral Hierarchy in Java. Anthropological Quarterly, 80(1), 5-37.

Agustian, A. (2016). Revolusi mental berbasis ESQ (Kecerdasan Emosi \& Spiritual). Jakarta: Arga Tilanta.

Alfian, M. A. (2018). Menggali etos kerja Pancasila. KOMPAS. Retrieved from https://kompas.id/baca/opini/2018/06/02/menggali-etos-kerja-pancasila/

Ali, H., \& Purwandi, L. (2017). Millennial Nusantara Pahami Karakternya, Rebut Simpatinya. Jakarta: PT Gramedia Pustaka Utama.

Anggorowati, \& Sarmini. (2015). Pelaksanaan Gotong Royong Di Era Global (Studi Kasus Di Desa Balun Kecamatan Turi Kabupaten Lamongan). Kajian Moral Dan Kewarganegaraan, 1(2), 39-53.

Aristiarini, A. (2017, October 25). Memahami Negeri Sendiri. KOMPAS.

Ariyantoni, D. (2014). Budaya Gotong Royong Bangsa Indonesia sebagai Common Identity dalam Wawasan Nusantara. Universitas Gadjah Mada, Yogyakarta.

Asean Economic Integration Brief. (2017). ASEAN Economic Integration Brief. No. 01. June. Jakarta: The ASEAN Secretariat.

Aslichati, L. (2011). Organisasi Pemberdayaan Dan Kesejahteraan Keluarga Sebagai Sarana Pemberdayaan Perempuan. Jurnal Organisasi Dan Manajemen, 7(1), 1-7.

Asnudin, A. (2010). Pendekatan Partisipatif dalam Pembangunan Proyek Infrastruktur Perdesaan di Indonesia. Jurnal SMARTek, 8(3), 182-190.

Azman, N., Halim, S. A., Liu, O. P., Saidin, S., \& Komoo, I. (2010). Public Education in Heritage Conservation for Geopark Community. Procedia - Social and Behavioral Sciences, 7, 504-511. https://doi.org/10.1016/j.sbspro.2010.10.068

Badan Pusat Statistik. (2010). Hasil Sensus Penduduk 2010 Kewargaan Suku Bangsa Agama, dan Bahasa Sehari-Hari Penduduk Indonesia.

Baker, J. (2006). Vigilantes and The State. Social Analysis: The International Journal of Social and Cultural Practice, 50(1), 203-207.

Baswedan, A. (2015, March). Kebudayaan Bagian Penting dalam Perbaikan Karakter. Swantara: Majalah Triwulan Lemhanas RI, 12.

Bintari, P., \& Darmawan, C. (2016). Peran Pemuda Sebagai Penerus Tradisi Sambatan Dalam Rangka Pembentukan Karakter Gotong Royong. Jurnal Pendidikan Ilmu Sosial, 25(1).

Bintarto, R. (1980). Gotong Royong: Suatu Karakteristik Bangsa. Surabaya: Bina Ilmu.

Blackburn, S. (2004). Women and The State in Modern Indonesia. Cambridge: Cambridge University Press.

Bourchier, D. (1998). Indonesianising Indonesia: Conservative Indigenism in An Age of Globalisation. Social Semiotics, 8(2), 203-214. 
Bowen, J. R. (1986). On the Political Construction of Tradition: Gotong Royong in Indonesia. The Journal of Asian Studies, 45(3), 545-561. https://doi.org/10.2307/2056530

Bowie, B. M. (1955). Sang Raksasa Muda: INDONESIA. National Geographic, 108(3), 22-41.

Brahmana, E. B., Rochayanti, C., \& Susilo, M. E. (2009). Nilai-nilai gotong-royong dalam tari mbuah page (analisis semiotika nilai-nilai gotong-royong dalam tari mbuah page pada acara adat merdang-merdem di Desa Perbesi Kecamatan Tigabinanga Kabupaten Karo Sumatera Utara). Jurnal Ilmu Komunikasi, 7(1).

Braithwaite, J. (2011). Anomie and Violence in Indonesia and Timor-Leste, 1997-2009. Asian Journal of Criminology, 6(1), 51-68. https://doi.org/10.1007/s11417-010-9087-2

Braithwaite, J. (2011b). Partial truth and reconciliation in the longue durée. Contemporary Social Science, 6(1), 129-146. https://doi.org/10.1080/17450144.2010.534498

Braithwaite, J. (2014). Traditional Justice. In J. J. Llewellyn \& D. Philpott (Eds.), Restorative Justice, Reconciliation, and Peacebuilding. https://doi.org/10.1093/acprof:oso/9780199364862.001.0001

Carnegie, M. (2010). Living with Difference in Rural Indonesia: What Can Be Learned For National and Regional Political Agendas? Journal of Southeast Asian Studies, 41(3), 449-481.

Darmaatmadja, J. (2017). Membangun Indonesia Melalui Gereja Katolik. In V. M. Murwaningsih (Ed.), Sinergi Bakti untuk Negeri: Berbagi Visi dan Refleksi Karya 95 Tahun Kanisius Berkarya. Yogyakarta: PT Kanisius.

Darwin, M. M. (2009). Revitalisasi Nasionalisme Madani Dan Penguatan Negara Di Era Demokrasi. In I. B. Praswanto, S. P. W. Baiquni, P. M. Kutanegara, \& G. Priyatmono (Eds.), Bulaksumur Menggagas Kesejahteraan Sosial: Pemikiran Guru Besar UGM. Yogyakarta: PT Purna Gama dan Penerbit Kanisius.

DeMeulenaere, S. (2002). Socio-Economic Solidarity through Community Exchange: Cooperation, Peace and Economic Justice. Africa \& Latin America. December: Network of Community Exchange Systems in Asia.

Departemen Pendidikan dan Kebudayaan. (1997). Pembinaan Nilai-Nilai Budaya Melalui Permainan Rakyat di Daerah Jambi. Jambi: Departemen Pendidikan dan Kebudayaan.

Dewantara, A. W. (2017a). Alangkah Hebatnya Negara Gotong Royong: Indonesia dalam Kacamata Soekarno. Yogyakarta: Kanisius.

Dewantara, A. W. (2017b). Diskursus filsafat Pancasila dewasa ini. Yogyakarta: Kanisius.

Dewantara, A. W. (2017c). Pendidikan Nilai Gotong-Royong Sebagai Strategi Ketahanan Nasional. Seminar Nasional KeIndonesiaan II Tahun 2017: Strategi Kebudayaan Dan Tantangan Ketahanan Nasional Kontemporer. Semarang: Universitas PGRI.

Dewi, A. (2007). Community-Based Analysis of Coping with Urban Flooding: A Case Study in Semarang, Indonesia (Research Paper). Netherlands. International Institute for Geo-information Science and Earth Observation.

Djamari. (2016). Penanaman Sikap Gotong Royong Dalam Kegiatan Ekstrakurikuler Pramuka Di SDN 3 Kronggen Grobogan. Universitas Muhammadiyah Surakarta.

Duwata, N. (2013). Aktualisasi nilai kekeluargaan (persaudaraan) dan nilai kegotongroyongan dalam permainan tarik tambang pada warga masyarakat RT 24 RW 06 Sidikan Umbulharjo Yogyakarta tahun 2012. Jurnal Citizenship, 2(1).

Effendi, T. N. (2013). Budaya Gotong-Royong Masyarakat dalam Perubahan Sosial Saat Ini. Jurnal Pemikiran Sosiologi, 2(1), 1-18. 
Farisi, M. I. (2014). Bhinneka Tunggal Ika [Unity in Diversity]: From Dynastic Policy to Classroom Practice. Journal of Social Science Education, 13(1). https://doi.org/61

Fathurokhman, F. (2013). The Necessity of Restorative Justice on Juvenile Delinquency in Indonesia, Lessons Learned from The Raju and AAL Cases. Environmental Sciences, 17, 967-975.

Fearnley-Sander, M. (2000). Preparation for Ethical Community: Learning from Education for Sittlichkeit in New Order Indonesia. Citizenship Studies, 4(3).

Firdaus, H., \& Riatmoko, F. I. (2015). Gotong Royong Untuk Menggapai Kemandirian: Pemimpin Kreatif. KOMPAS. December.

Gani, D. S. (2004). Leadership in Indonesia: A Case for Managing Relationship Within Organizations. In D. Tjosvold \& K. Leung (Eds.), Leading in High Growth Asia: Managing relationship for teamwork and change. Singapore: World Scientific Publishing Co.

Garfield, J. (1993). Teaching Statistics Using Small-Group Cooperative Learning. Journal of Statistics Education, 1(1). Retrieved from www.amstat.org/publications/jse/v1n1/garfield

Geertz, C. (1983a). From The Native's Point of View: On The Nature of Anthropological Knowledge. In C. Geertz (Ed.), In Local Knowledge: Further Essays in Interpretive Anthropology (pp. 55-70). New York: Basic Books.

Geertz, C. (1983b). Local Knowledge: Further essays in interpretive antrophology. New York: Basic Books.

Ghazali, S. (2013). Sense of place and the politics of "Insider-Ness" in Villages undergoing transition: the case of City Kampung on Penang Island. In Cleavage, Connection and Conflict in Rural, Urban and Contemporary Asia (pp. 117-142). Dordrecht: Springer.

Goodfellow, R. (1997). Indonesian Business Culture. Singapore: Butterworth-Heinemann Asia.

Goodwin, R., \& Giles, S. (2003). Social Support Provision and Cultural Values in Indonesia and Britain. Journal of Cross-Cultural Psychology, 34(10), 1-6.

Guinness, P. (1986). Harmony and Hierarchy in a Javanese Kampong. Singapore: Oxford University Press.

Guinness, P. (1994). Local Society and Culture. In H. Hill (Ed.), Indonesia's New Order: The Dynamics of Socio-Economic Transformation (pp. 267-304). Honolulu: University of Hawaii Press.

Gunardo, R. B. (2013). Karakter gotong royong warga dalam menghadapi bencana banjir lahar dingin merapi di Kota Yogyakarta. Jurnal Penelitian Humaniora, 18(2), 156-165.

Handoko, A. (2016, August). Gotong Royong Bayar Iuran: Jaminan Sosial. KOMPAS.

Hardiman, B. (1980). Kritik Atas Patologi Modernitas dan Post Modernisme. Driyakarya, 2(19), $42-63$.

Harinto. (2018, March 6). Gotong royong: Mengintip “Istana Negara” di Pelosok Desa. KOMPAS.

Harjosusanto, Y. (2017). Masih Mungkinkah Dialog Iman Antar Umat Beragama. In V. M. Murwaningsih (Ed.), Sinergi Bakti untuk Negeri: Berbagi Visi dan Refleksi Karya 95 Tahun Kanisius Berkarya. Yogyakarta: PT Kanisius.

Harmoni, A. (2015). Pendidikan Karakter Bangsa di Perguruan Tinggi guna Memperkokoh Ketahanan Nasional. LEMHANAS RI, 23.

Harnoko, D., \& Salamun. (2016). Biografi Widayat Djiang: Sebuah Sketsa Kehidupan Dalang Peranakan Tionghoa. Yogyakarta: Balai Pelestarian Nilai Budaya. 
Hasan, S., \& Onyx, J. (2008). Third Sector Growth and Governance: Contexts, and Traditions in Asia. In Comparative Third Sector Governance in Asia (pp. 19-37). New York: Springer.

Hisyam, M. (2003). Krisis Masa Kini dan Orde Baru. Jakarta: Yayasan Obor.

Hofstede, G. (1994). Cultures and organizations: software of the mind. London: Harper-Collins Publishers.

Hudalah, D., Zulfahmi, F., \& Firman, T. (2013). Regional governance in decentralizing Indonesia: Learning from the success of urban-rural cooperation in metropolitan Yogyakarta. In Cleavage, connection and conflict in rural, urban and contemporary Asia (pp. 65-82). Dordrecht: Springer.

Indiyani, N., \& Listiara, A. (2006). Efektivitas Metode Pembelajaran Gotong Royong (Cooperative Learning) Untuk Menurunkan Kecemasan Siswa Dalam Menghadapi Pelajaran Matematika (Suatu studi Eksperimental pada Siswa di SMP 26 Semarang). Jurnal Psikologi Universitas Diponegoro, 3(1), 10-28.

Irawan, K. I. (2018, June 11). Toleransi: Indonesia Mini Di Dusun Tertinggi. KOMPAS.

Irawanto, D. W. (2015). Employee Participation in Decision-Making: Evidence from A State-Owned Enterprise in Indonesia. Management, 20(1), 159-172.

Jamal, S., \& Pomp, M. (1993). Smallholder Adoption of Tree Crops: A Case Study of Cocoa in Sulawesi. Bulletin of Indonesian Economic Studies, 29(3), 94.

Jetschke, A., \& Rüland, J. (2009). Decoupling Rhetoric and Practice: The Cultural Limits of ASEAN Cooperation. The Pacific Review, 22(2), 179-203.

Joesoef, D. (2017). Membangun Budaya Bangsa dan Nilai Keindonesiaan Demi Masa Depan Bangsa. In Sularto \& A. Paramita (Eds.), Nilai Keindonesiaan: Tiada bangsa besar tanpa budaya kokoh. Jakarta: PT Kompas Media Nusantara.

Kaming, P. F., Holt, G. D., Kometa, S. T., \& Olomolaiye, P. O. (1998). Severity Diagnosis of Productivity Problems: A Reliability Analysis. International Journal of Project Management, 16(2), 107-113.

Kamsori, M. E., Santosa, A. B., \& Moe'is, S. (2007). Dinamika Kehidupan Masyarakat Perkotaan (Edisi 3). Bandung: Anggita Pustaka Mandiri.

Kasali, R. (2017). Disruption. Jakarta: Penerbit PT Gramedia Pustaka Utama.

Kawagoe, T., Ohkama, K., \& Bagyo, A. S. (1992). Collective Actions and Rural Organizations in A Peasant Economy in Indonesia. The Developing Economies, 30(3), 215-235.

Kayam, U. (1987). Keselarasan dan Kebersamaan: Suatu Penjelajahan Awal. Prisma, 16(3), 251-261.

Kemendikbud. Peraturan Menteri Pendidikan dan Kebudayaan Republik Indonesia Nomor 160 Tahun 2014 tentang Pemberlakuan Kurikulum Tahun 2006 dan Kurikulum 2013. , Kurikulum Tahun 2006 dan Kurikulum 2013 pada Sekolah Jenjang Pendidikan Dasar dan Pendidikan Menengah § (2014).

Kementerian Koordinator Bidang Pembangunan Manusia dan Kebudayaan. (2015, December 8). Gotong Royong Biopori, Gerakan Kerelawanan. KOMPAS.

Kementerian Perencanaan Pembangunan Nasional/ Badan Perencanaan Pembangunan Nasional. (2014a). Rencana Pembangunan Jangka Menengah Nasional 2015-2019 Buku I: Agenda Pembangunan Bidang.

Kementerian Perencanaan Pembangunan Nasional/ Badan Perencanaan Pembangunan Nasional. Rencana Pembangunan Jangka Menengah Nasional 2015-2019 Buku II: Agenda Pembangunan Bidang. , (2014).

Kemko Kesejahteraan Rakyat. (2010). Kebijakan Nasional Pembangunan Karakter Bangsa. Jakarta: Kemko Kesejahteraan Rakyat. 
Khasanah, N. (2013). Pengejawantahan nilai-nilai dalam pengembangan budaya gotong royong di era digital. Edukasi, 1(1), 92-108.

Koentjaraningrat. (1961). Gotong Rojong: Some Social Anthropological Observation on Practices in Two Villages of Central Java (C. Holt, Ed.). United Kingdom: Equinox Publishing.

Koentjaraningrat. (1967). Beberapa Pokok Antropologi Sosial. Jakarta: Dian Rakyat.

Koentjaraningrat. (1988). The Indonesian mentality and development. Journal of Social Issues in Southeast Asia, 3(2), 107-133. Retrieved from https://www.jstor.org/stable/41057106

KOMPAS. (2015). Budaya Gotong Royong.

Kurniawan, S. (2015). Revolusi Mental Making Indonesia WOW. Jakarta: Marketeers.

Kusumasari, B., \& Alam, Q. (2012). Local wisdom-based disaster recovery model in Indonesia. Disaster Prevention and Management: An International Journal, 21(3), 351-369. https://doi.org/10.1108/09653561211234525

Latif, Y. (2015). Keharusan revolusi mental. In J. Sinamo (Ed.), Menggulirkan Revolusi Mental di Berbagai Bidang. Jakarta: Institut Darma Mahardika.

Latif, Y. (2017). Relevansi Pancasila dalam hidup kekinian. In Sularto \& A. Paramita (Eds.), Nilai Keindonesiaan: Tiada Bangsa Besar Tanpa Budaya Kokoh. Jakarta: PT Kompas Media Nusantara.

Lembaga Ketahanan Nasional Republik Indonesia. (2015). Modul Bidang Studi Pancasila dan UUD Negara RI 1945. Sub Bidang Studi UUD NRI 1945 dan Permasalahannya. Program Pendidikan Singkat Angkatan (PPSA) XX. In Sub Bidang Studi UUD NRI 1945 dan Permasalahannya. Jakarta: Lembaga Ketahanan Nasional Republik Indonesia.

Lie, A. (2002). Cooperative Learning: Mempraktikkan Cooperative Learning di Ruang-Ruang Kelas. Jakarta: Gramedia Widiasarana Indonesia.

Lim, J., Chan, M. M. H., Alsagoff, F. Z., \& Ha, D. (2014). Innovations in non-communicable diseases management in ASEAN: a case series. Global Health Action, 7(1), 25110. https://doi.org/10.3402/gha.v7.25110

Macrae, G. (2008). Could the system work better? Scale and local knowledge in humanitarian relief. Development in Practice, 18(2), 190-200. https://doi.org/10.1080/09614520801898970

Magnis-Suseno, F. (1997). Javanese Ethics and World-View: The Javanese Idea of Good Life. Jakarta: PT Gramedia Pustaka Utama.

Maharani, P. (2015, March). Gotong Royong Sumber Daya Terbesar Kita Membangun Bangsa. Swantara. Majalah Triwulan Lemhanas RI No. 12, 4.

Mahkamah Konstitusi Republik Indonesia. (2010). Naskah Komprehensif Perubahan Undang-Undang Dasar Negara Republik Indonesia Tahun 1945: Latar Belakang, Proses, dan Hasil Pembahasan, 1999-2002. Buku III: Lembaga Pemusyawaratan dan Perwakilan. Jilid 1. Edition Revisi (Vol. 1). Jakarta: Sekretariat Jenderal dan Kepaniteraan Mahkamah Konstitusi.

Mahkamah Konstitusi Republik Indonesia. (2017). Laporan Tahunan 2016: Harmoni Sosial dan Budaya Demokrasi yang Berkeadilan. Cetakan Pertama. Jakarta: Kepaniteraan dan Sekretariat Jenderal Mahkamah Konstitusi.

Manurung, L., Sumarto, H. S., Komariya, Y., \& McIntyre-Mills, J. (2009). Identity in Post Suharto Indonesia. Syst Pract Action Res, 22, 149-171. 
Marcillia, S. R., \& Ohno, R. (2012). Learning from Residents' Adjustments in Self-Built and Donated Post Disaster Housing After Java Earthquake 2006. Social and Behavioral Sciences, 36, 61-69.

McCarthy, J. F. (2014). Using community led development approaches to address vulnerability after disaster: Caught in a sad romance. Global Environmental Change, 27, 144-155. https://doi.org/10.1016/j.gloenvcha.2014.05.004

Mohamad, Z. F., Idris, N., \& Mamat, Z. (2012). Role of Religious Communities in Enhancing Transition Experiments: A Localised Strategy for Sustainable Solid Waste Management in Malaysia. Sustain Science, 7, 237-251.

Munaldus. (2015). Revolusi Mental di Koperasi. In J. Sinamo (Ed.), Menggulirkan Revolusi Mental di Berbagai Bidang. Jakarta: Institut Darma Mahardika.

Muryanti. (2014). Revitalisasi gotong royong: Penguat persaudaraan masyarakat Muslim di pedesaan. Sosiologi Reflektif, 9(1).

Mustaqim, A. H. (2013). Gotong Royong Dalam Dwilogi Padang Bulan dan Cinta Di Dalam Gelas Karya Andrea Hirata (Sebuah Kajian Sosiologi Sastra). WANASTRA, 4(1).

Musthofa, K. (2013). Pembelajaran Fisika Dengan Cooperative Learning Tipe Jigsaw untuk Mengoptimalkan Aktivitas dan Kemampuan Kognitif Siswa Kelas X-6 SMA MTA Surakarta. Jurnal Pendidikan Fisika, $1(1), 55-63$.

Nasution, Z. (2010). Konflik dan Lunturnya Solidaritas Sosial Masyarakat Desa Transisi. Retrieved June 15, 2019, from http://berkarya.um.ac.id/2010/02/konflik-dan-lunturnya-solidaritas-sosial

Nelson, L. P. (2008). A Resiliency Profile of Hurricane Katrina Adolescent: A Psychosocial Study of Disaster. Canadian Journal of School Psychology, 23, 57-69.

Newberry, J. (2007). Rituals of Rule in the Administered Community: The Javanese Slametan Reconsidered. Modern Asian Studies, 41(6), 1295-1329. https://doi.org/10.1017/S0026749X06002575

Panggabean, H., Tjitra, H., \& Murniati, J. (2014). Kearifan Lokal Keunggulan Global: Cakrawala Baru di Era Globalisasi. Jakarta: PT Elex Media Komputindo.

Panglaykim, J. (1965). Worker-Management Councils in Indonesia. World Politics, 17(2), 243-255. https://doi.org/10.2307/2009350

Pasya, G. K. (1987). Gotong Royong Dalam Kehidupan Masyarakat. Prisma, 3, 18-27.

Pattiradjawane, R. L., \& Soebagjo, N. (2015). Global maritime axis: Indonesia, China, and a new approach to Southeast Asian regional resilience. International Journal of China Studies, 6(2), 175-185.

Pattisina, E. C., \& Anggoro, A. P. (2018). Keberagaman yang Membangun. In M. Hernowo (Ed.), Membaca Indonesia \#Menyatukan Kepingan. Jakarta: Kompas Media Nusantara.

Pierewan, A. C., \& Sujarwoto. (2010). Gotong Royong and Mental Health in Indonesia. The First International Conference Of Indigenous \& Cultural Psychology. Yogyakarta: Universitas Gadjah Mada.

Prabowo, E. E. (2015, March). Revolusi Mental Dimulai Dari Mana? Lemhanas RI. No.12. Tahun IV.

Pranadji, T. (2009). Penguatan Kelembagaan Gotong Royong dalam Perspektif Sosio Budaya Bangsa. Jurnal Forum Penelitian Agro Ekonomi, 27(1), 61-72.

Pranowo, M. B. (2010). Multidimensi Ketahanan Nasional. Jakarta: Pustaka Alvabet.

Prasetyo, K. B. (2009). Menjadi Aceh di Panti Asuhan: Studi tentang Sosialisasi Anak Aceh di Panti Asuhan 
Pasca Bencana. Yogyakarta.

Prawitasari-hadiyono, J. E., Paramastri, I., Suhapti, R., Novianti, P., Widiastuti, T. R., \& Rengganis, N. (2009). Social Artistry, Local Wisdom, and Post Earthquake Conflict. Retrieved from www.springerlink.com.

Purna, I. M., \& Wahyuningsih, R. A. (1996). Macapat dan Gotong Royong. Jakarta: CV Putra Sejati Raya.

Putnam, R. D. (1993). The Prosperous Community: Sosial Capital and Public Life. The American Prospect No. 13,4 .

Putra, C. K., \& Pratiwi, R. N. andSuwondo. (2013). Pengelolaan Alokasi Dana Desa Dalam Pemberdayaan Masyarakat Desa (Studi pada Desa Wonorejo Kecamatan Singosari Kabupaten Malang). Jurnal Administrasi Publik, 1(6), 1203-1212.

Putra, W. W. (2018, August 8). Jangan Khianati Ideologi Bangsa. KOMPAS.

Rachman, E., \& Savitri, S. (2011, July 16). Gotong Royong. KOMPAS.

Rafik-Galea, S., Mello, G. de., \& Dass, I. C. (2013). Cultural Influences on Group Learning in an ESL Classroom. Review of European Studies, 5(2).

Rahayu, S., Ludigdo, U., Irianto, G., \& Nurkholis. (2015). Budgeting of school operational assistance fund based on the value of gotong royong. Social and Behavioral Sciences, 211, 364-369.

Rahmi, D. H., Wibisono, B. H., \& Setiawan, B. (2001). Rukun and Gotong Royong: Managing Public Places in an Indonesian Kampung. In P. Miao (Ed.), Public Places in Asia Pacific Cities: Current Issues and Strategies (pp. 119-134). Dordrecht: Kluwer Academic Press.

Rajiani, I., \& Jumbri, I. A. (2011). A Cultural Ecology of New Public. Management in Indonesia Journal of Administrative Science, 8(1), 17-31.

Reimer, B. (1995). Gender, Feminism, and Aesthetic Education: Discourses of Inclusion and Empowerment. Philosophy of Music Education Review, 3(2), 107-124.

Rigg, J., Allott, A., Harrison, R., \& Kratz, U. (1999). Understanding languages of modernization: a southeast asian view. Modern Asian Studies, 33(3), 581-602.

Riyadi, Y. (2017, June 14). Gotong Royong Terjemahkan Bencana: Teknologi Informasi. KOMPAS.

Rizqi, F. (2017, December). Pancasila Perlu Diaktualisasikan. Swantara. Majalah Triwulan Lemhanas RI. Swantara. Majalah Triwulan Lemhanas RI. No.23. Tahun VI.

Rochmadi, N. (2012). Gotong royong sebagai common identity dalam kehidupan bertetangga negara-negara Asean. Jurnal Forum Sosial Universitas Negeri Malang, 9(40).

Rother, S. (2007). West Goes East: The ASEAN Logic of Anarchy. Presented in the section 'The Contribution of Regional and Area Studies to IR Theory. The Sixth Pan European International Relations Conference (SGIR). European Consortium of Political Research (ECPR). University of Turin.

Sadilah, E., Mudjijono, \& Budi, N. S. (2015). Etnografi Masyarakat Desa Randualas: Kajian Budaya SantetanJagong. Yogyakarta: Balai Pelestarian Nilai Budaya (BPNB).

Sadjad, S. (2013). Karakter bangsa. KOMPAS.

Sagala, S., Okada, N., \& Paton, D. (2009). Predictors of Intention to Prepare for Volcanic Risks in Mt Merapi, Indonesia. Journal Of Pacific Rim Psychology, 3(2), 47-54.

Salamun, Sumintarsih, \& Wuryansari, T. E. (2015). Komunitas Adat Using Desa Aliyan Rogojampi Banyuwangi 
Jawa Timur: Kajian Ritual Keboan. Yogyakarta: Balai Pelestarian Nilai Budaya (BPNB).

Salehudin, M. S., Prasad, D., \& Osmond, P. (2013). A Field Survey Of Local Community Empowerment Initiatives At Selected Resort In Malaysia. Conference of the International Journal of Arts \& Sciences, $6(1), 445-452$.

Saliyo. (2012). Konsep Diri dalam Budaya Jawa. Buletin Psikologi, 20(1-2), 26-35.

Salsabila, A. (2017). Merajut Kebhinnekaan Melalui Penguatan Nilai-Nilai Kebangsaan. Swantara. Majalah Triwulan Lemhanas RI. No.23. Tahun VI.

Samawi, I. (2016, May). Gotong Royong dan Kearifan Lokal Kunci Utama Kebangkitan Bantul: Kenangan HM Idham Samawi. Kedaulatan Rakyat.

Sambhi, N. (2015). Jokowi’s “Global Maritime Axis”: Smooth Sailing or Rocky Seas Ahead? Security Challenges, 11(2), 39-55.

Saputra, F. X. L. A. (2015, December 3). Gotong Royong Mulai Akhir 2015. KOMPAS.

Saraswati, R. (2011). Budaya Gotong Royong Dan Implikasinya Terhadap Ketahanan Sosial Budaya Di Era Globalisasi (Studi Kasus Pada Masyarakat Cisaranten Endah). Universitas Gadjah Mada.

Sarwono, S. W. (2017). Keteladanan Penyelenggara Negara dan Penguatan Mentalitas Pelayanan. In Sularto \& A. Paramita (Eds.), Nilai Keindonesiaan: Tiada Bangsa Besar Tanpa Budaya Kokoh. Jakarta: PT Kompas Media Nusantara.

Satrijono, H. (2012). Penerapan Pembelajaran Kooperatif dengan Teknik Dua Tinggal Dua Bertamu (Two Stay Two Stray). Jurnal Ilmu Pendidikan Sekolah Dasar, 1(2), 166-182.

Sekretariat Negara Republik Indonesia. Undang-Undang RI Number 17 Tahun 2007 tentang Rencana Pembangunan Jangka Panjang 2005-2025. , (2007).

Setiawan, D. (2013). Peran pendidikan karakter dalam mengembangkan kecerdasan moral. Jurnal Pendidikan Karakter Tahun III, 1, 53-63. https://doi.org/https://doi.org/10.21831/jpk.v0i1.1287

Sihombing, S. O., \& Pongtuluran, F. D. (2011). Pengidentifikasian Dimensi-Dimensi Budaya Indonesia: Pengembangan Skala Dan Validasi. Seminar Nasional Sustainable Competitive Advantage-1, 1-17. Universitas Jenderal Soedirman.

Sillifant, J. (1994). Lokakarya Dusun: Building Community Self-Reliance And Community Input To The Development Process In Central Sulawesi, Indonesia. Peace Research, 26(1), 41-59.

Simarmata, H. T., Sunaryo, F., Purnama, C. S., Susanto, A., Nurjanah, N., Rizal, G. N., \& Sapei, A. (2017). Indonesia: Emerald Chain of Tolerance (1st ed). Jakarta: Pusat Studi Islam dan Kenegaraan Indonesia (PSIK-Indonesia).

Soedirham, O. (2012). Integrated Services Post (Posyandu) as Sociocultural Approach for Primary Health Care Issue. Jurnal Kesehatan Masyarakat Nasional, 7(5), 195-198.

Soekamto, S. (1986). Sosiologi Suatu Pengantar. Jakarta: CV. Rajawali.

Solihin, D. (2015). Implementasi Revolusi Mental Melalui Kebijakan Strategi dan Upaya. Swantara. Majalah Triwulan Lemhanas RI No.12. Tahun IV.

Sudarmadji, \& Darmanto, D. (2014). Dampak Lingkungan Dan Risiko Bencana Pengembangan Desa Wisata Studi Kasus Di Desa Wisata Sambi. Kawistara, 4(2), 111-224.

Sudarto, Y. (2006). E-Goverment Dan Reformasi Birokrasi Menuju Pemerintahan Yang Baik. Proceeding of 
Konferensi Nasional Teknologi Informasi \& Komunikasi Untuk Indonesia, 3, 44-47. Institut Teknologi Bandung.

Sugiyanto, \& Khamadi. (2011). Perancangan Game Edukasi "Semangat Si Semut'” Sebagai Media Untuk Menanamkan Semangat Gotong Royong Pada Anak Usia Din.” Techno.COM, 10(1), 35-40.

Sultani. (2016, November 14). Modal Sosial Jadi Penangkal Konflik: Jajak pendapat KOMPAS. KOMPAS.

Sumarijanto, M. (2013, June). Pancasila Adalah Roh Kehidupan Berbangsa. Swantara. Majalah Triwulan Lemhanas RI. No.5. Tahun II.

Suprihatin, I. (2014). Perubahan Perilaku Bergotong Royong Masyarakat Sekitar Perusahaan Tambang Batubara Di Desa Mulawarman Kecamatan Tenggarong Seberang. Journal Sosiatri, 1(3), 63-77.

Surbakti, R. (2009). Memahami ilmu politik. Jakarta: Grasindo.

Suryohadiprojo, S. (2016). Budaya Gotong Royong dan Masa Depan Bangsa. Jakarta: PT Kompas Media Nusantara.

Susanti, F., Siswati, \& Widodo, P. B. (2010). Pengaruh Permainan Tradisonal Ttrhadap Kompetensi Interpersonal dengan Teman Sebaya pada Siswa SD (Studi Eksperimental pada Siswa Kelas 3 SDN Srondol Wetan 04-09 dan SDN Srondol Wetan 05-08). Jurnal Psikologi Undip, 8(2), 145-155.

Susanto, E. H. (2016). Komunikasi dan Gerakan Perubahan: Kemajemukan dalam Konstelasi Sosial, Ekonomi, Politik. Jakarta: Mitra Wacana Media.

Sutrisno, F. X. M. (2017). Rumah Makna. In St. Sularto \& A. Paramita (Eds.), Nilai Keindonesiaan: Tiada Bangsa Besar Tanpa Budaya Kokoh. Jakarta: PT Kompas Media Nusantara.

Suwondo, B. (1982a). Sistem Gotong royong dalam masyarakat pedesaan daerah DIY. Jakarta: Depdikbud.

Suwondo, B. (1982b). Sistem Gotong Royong dalam Masyarakat Pedesaan Daerah Sulawesi Tenggara. Jakarta: Depdikbud.

Suwondo, B. (1983a). Sistem Gotong Royong dalam Masyarakat Pedesaan Daerah Sulawesi Tengah. Jakarta: Depdikbud.

Suwondo, B. (1983b). Sistem Gotong royong dalam masyarakat pedesaan daerah Sumatera Barat. Jakarta: Depdikbud.

Swasono, S. E. (2017). Demokrasi Ekonomi Untuk Keberdaulatan Dan Kemandirian. In Sularto \& A. Paramita (Eds.), Nilai Keindonesiaan: Tiada Bangsa Besar Tanpa Budaya Kokoh. Jakarta: PT Kompas Media Nusantara.

Syamsuddin, D. (2016, June 21). Kemajemukan Modal Nasional Indonesia: Nilai Kebangsaan. KOMPAS.

Takwin, B. (2015). Revolusi Mental Melalui Pembangunan Sosial. In H. Panggabean, A. Supratiknya, \& J.S.A.Utama (Eds.), Revolusi Mental: Makna dan Realisasi. Seri Sumbangan Pemikiran Psikologi Untuk Bangsa (Jakarta). Himpunan Psikologi Indonesia.

Taylor, P. M., \& Aragon, L. V. (1991). Beyond the Java Sea: Art of Indonesia's Outer Islands. Abrams.

Thohir, E. (2018, September 2). Sukses Berkat Gotong Royong. KOMPAS.

Thomas, V. B., Selvadurai, S., Er, A. C., Lyndon, N., \& Moorthy, R. (2011). Factors influencing commitment of volunteers' in neighborhood watch organization. Journal of Social Sciences, 7(4), 569-574.

Timur, A. (2016, June 27). Gotong Royong di Era Digital: Penggalangan Dana Sosial Memanfaatkan 
Teknologi. KOMPAS.

Tjahjandari, L., Setyani, T. I., Pembayun, P. S., \& Kurnia, L. H. (2017). Culture As A Capital To Improve The Local Economy Case Study In Cibuntu Village, Kuningan. Proceeding The 3 International Indonesian Forum for Asian Studies: Borderless Communities \& Nations with Borders Challenges of Globalisation. Universitas Gadjah Mada \& Universitas Islam Indonesia Yogyakarta.

Toisuta, W. (2017). Peran Pendidikan dalam Pengembangan Nilai Keindonesiaan. In Sularto \& A. Paramita (Eds.), Nilai Keindonesiaan: Tiada bangsa besar tanpa budaya kokoh. Jakarta: PT Kompas Media Nusantara.

Tsamenyi, M., Noormansyah, I., \& Uddin, S. (2008). Management Controls in Family-Owned Businesses (FOBs): A Case Study of An Indonesian Family-Owned University. Accounting Forum, 32, 62-74.

Wachtendorf, T., Brown, B., \& Nickle, M. (2008). Big Bird, Disasters Masters and High School Students Taking Charge: The Social Capacities of Children in Disaster Education. Children, Youth, and Environments, 18(1), 456-469.

Wahid, Y. (2016, May 20). Kaum Muda Optimis Bersaing Di Skala Global: Kebangkitan Nasional Dimaknai Dalam Konteks Kekinian. KOMPAS.

Wihantoro, Y., Lowe, A., Cooper, S., \& Manochin, M. (2015). Bureaucratic Reform in Post-Asian Crisis Indonesia: The Directorate General of Tax. Critical Perspectives on Accounting, 31, 44-63.

Wirutomo, P. (2015a). Mewujudkan revolusi mental. In J. Sinamo (Ed.), Menggulirkan revolusi mental di berbagai bidang. Jakarta: Institut Darma Mahardika.

Wirutomo, P. (2015b). Revolusi Mental Untuk Indonesia. Swantara. Majalah Triwulan Lemhanas RI. Swantara: Majalah Triwulan Lemhanas RI No.12. Tahun IV.

Yatmo, Y. A., Atmodiwirjo, P., \& Paramita, K. D. (2013). Whose Waste Is It Anyway? Journal of Urban Design, 18(4), 534-552.

Yuniarti, K. W. (2009). The Magical Strength of Nrimo and Gotong Royong. A Quick Response Report Following The May 27, 2006 Earthquake In Yogyakarta. Anima. Indonesian Psychological Jounal, 24(3), 201-206.

Yunus, R. (2013). Transformasi Nilai-Nilai Budaya Lokal sebagai Upaya Pembangunan Karakter Bangsa (Penelitian Studi Kasus Budaya Huyula di Kota Gorontalo). Jurnal Penelitian Pendidikan, 14(1), 67-79.

Zakaria, H. G. (2017). 5 Pilar Revolusi Mental: Untuk Aparatur Negara. Jakarta: Penerbit PT Elex Media Komputindo.

Zanegoebel. (2010). Identity and Social Conduct in A Transient Multilingual Setting. Language in Society, 39, 203-240. 